We may be led from the consideration of the broad facts nature to conceptions of the most abstract kind, without being conscious of the slightest gap between the facts of Science and the creations of the Imagination. In these days the utmost skill is often displayed in hiding and ignoring or denying the hiatus by which the arguments cleduced from the results of observation and experiment are separated from those which are based upon the fictions of the fancy. But, unhappily, the gulf cannot be filled up, or bridged over. It may be obscured by mists and clouds, but, thongh it be lost for a time, it is sure to be rediscovered and its limits studied by the curious and unphilosophical.

Nowadays analogical argument is employed very freely without any attempt to show, in the first place, that there is any real analogy between the facts upon which the reasoning is based. In order to convince people that a hypothetical gemmule may move long distances through all sorts of tissues, it is only necessary to show that actual matter, millions of times as large, does burrow a short distance through certain textures. Mr. Darwin remarks that it cannot be objected "that the gemmules could not pass through tissues or cell-walls, for the contents of each pollen grain have to pass through the coats both of the pollen tube and embryonic sack."

He might have advanced in his support the fact of fungi traversing tissues, of entozoa of various kinds burrowing long distances through the textures of the living body, and many wellknown instances of a similar kind. But such facts do not strengthen the hypothesis of Pangenesis in the slightest degree. They were known before it was advanced, and the objection controverted has not been raised in the form indicated. We know that a thing infinitely larger than the hypothetical gemmule does pass through tissues, but do the gemmules really exist, and do they pass through ? Certainly, if they exist, they may pass, but, as I have indicated, there are other matters invalidating the hypothesis besides the question of the gemmules traversing the tissues. Pangcnetic gemmules might pass everywhere. They might leave the body, collect in the atmosphere and coalesce, and the compound particle formed might easily wriggle itself back again into the organism through the chinks between the cuticular cells. Such gemmules might move anywhere, up and down and in and out through any cell wall. They might pervade solids and fluids and gases. The pangenetic gemmule cannot be seen or tested, neither can its presence or absence be proved in any way. The phenomena adduced by Mr. Darwin in support of his hypothesis can be demonstrated; but the pangenetic gemmules are of the imagination alone, and the analogy between the actual facts and the supposed facts is surely but an analogy of theimagination. The facts alluded to no more support the pangenetic hypothesis than does the demonstration of living germs in the air support the hypothesis of life in the blue sky. It is possible to supply many arguments stronger than those adduced in support of the hypothesis, nay, perhaps, stronger than any Mr. Darwin himself has yet advanced in favour of Pangenesis; but yet other considerations appear to me greatly to preponderate against the acceptance of the doctrine. Mr. Darwin admits that "from presenting so many vulnerable points" the life of his hypothesis "is always in jeopardy ;" but is it not this very jeoparty which lends interest and enchantment to many a hypothesis, and sustains it in the estimation of those who delight in conjectural information and scientific speculation?

LIONEL S. BEALE

MR. Darwin, in his letter to Nature of April the 27th, says: "The fundamental laws of growth, reproduction, in. heritance, \&c., are so closely similar throughout the whole organic kingdom that the means by which the gemmules (assuming for the moment their existence) are diffused through the body, would probably be the same in all beings, therefore the means can hardly be diffusion through the blood." Now, if in the vegetable lingdom pangenetic gemmules are able freely to be "diffused" from cell to cell by endosmosis, we should expect that in the case of grafis, where certainly such diffusion goes on between the cells of the stock and the scion, a bud borne upon the graft would certainly be affected by the gemmules arising in the root and stem of the stock. Yet we all know that the pips from a pear grafted on a quince stock will not give rise to a hybrid between a pear and a quince, neither will the stone of a peach which has been grafted on a plum stock grow into a tree whose stock bears plums, while the extremities of its hranches bear peaches.
A. C. Ranyard

\section{Noises at Sea off Greytown}

IN NATURL, vol. ii. p. 25, Mr. Dennehy gave an interesting account of a peculiar vibration, accompanied by sound, which is perceivable at night on buard all (?) iron steamers which anchor off Greytown, Central America; and in subsequent pages I have read with great interest various speculations as to its origin, which is ascribed ( $\mathrm{f}$, the probable solution) to troops of Scirenoids (with reservation) by Mr. Kingsley (p. 46); (2) to musical fish or shells, by Messrs. Evans and Lindsay (pp. 46 and 356); and (3) to gas-escape from vegetable mud and sand, by $\mathrm{Mr}$. Malet (p. 47); whilst Mr. Dennehy himself suggests the possibilicy of some galvanic agency.

I remarked upon this vibratory phenomenon in a communication published in the Field newspaper of October 26th, 1867, signed "Ubique," after having heard it myself when on board the Royal Mail steamer Danube (Capt. Reeks) during the nights of the I2th, 1 $3^{\text {th }}$, I4th, and $15^{\text {th }}$ of May, 1867 ; the new moon occurring on the $4^{\text {th }}$ of the same month. As my statement serves to confirm Mr. Dennehy's report, I may be forgiven for giving it in full.

After giving an account of the sudden appearance of a huge white shark in the deep sea when a man fell overboard, I proceeded to state as follows:- "On embarking on board the Danube steamer, lying at anchor in the roadstead off Greytown on the I2th May, I867, I was informed that the ship was haunted by most curious noises at night since she had arrived, and that the superstitious black sailors were much frightened at what they thought must be a ghost. The captain and officers could make nothing of it, and it afforded a great matter for discussion. On inquiry I found out that nther iron ships had been similarly affected. Curiously enough this noise was only heard at night, and at certain hours. Some attributed it to fish, suckers, turtle, \&c., others to the change of tide or current; but no satisfactory conclusion cotild be arrived at. When night came on there was no mistake about the noise; it was quite loud enough to awaken me, and could be heard distinctly all over the ship. It was not dissimilar to the high monotone of an Eolian harp, and the noise was evidently caused by the vibration of the plates of the iron hull, which could be sensibly perceived to vibrate. What caused this pectiliar vibration? Not the change of current and tide, because, if so, it would be heard by day. Like everything else that we cannot explain, I suppose we must put it down to electricity, magnetism, \&c. If this should meet the eye of any of the officers of the above-mentioned steamer, or others who have noticed this phenomenon, I should be glad to hear whether this effect still continues, or if any satisfactory conclusion has yet been arrived at. I may add that from the hold of the vessel the grunts of the toad-fish could be distinctly heard. I hope that the above notice may lead to some answers from your various correspondents."

This brief notice drew forth a rejoinder from a correspondent (November 23, 1867) who had noticed a somewhat similar sound.

"'The singular sound noticed by 'Ubique,' I have also heard without knowing its origin. One moonlight night in 1854 , on board a steamer anchored near the Tavoy river (Tenasserim) we were struck by an extraordinary noise which appeared to proceed from the shore about a quarter of a mile off, or from the water in that direction. It was something like the sound of a stocking loom, but shriller, and lasted perhaps five or six seconds, producing a sensible concussion on the ear like the piercing scream of the cicada; and this gave an impression as if the vessel itself were trembling, or reverberating from the sound. One or two Burmans on board said simply, the noise was produced by 'fishes,' but of what kind they did not describe. It was repeated two or three times. I never heard it before or after the occasion referred to, nor have I ever mel with any allusion to this singular phenomenon until I perused "Ubique's' communication in the Field of the 26 th ult. The steamer in my case, I should add, was a wooden one."

Mr. Evans, in his letter, speaks of the rapid silting up of Greytown harbour this still continues, and the passage over the bar, which is continually shifting, is often a matter of great difficulty, and indeed o'ten so dangerous that the Royal Mail Company will not undertake to allow their own boats to land, and passengers have to land in the local canoes at their own risk. The Nicaraguan Government, however, propose to carry out Mr. Shepherd's plan of diverting the waters of the San Juan river from the Colorado mouth to the Greytown channel, hoping thereby to scour the harbour clear. 